Samuel Wai Johnson Jr.'

\title{
Post-Conflict Reconstruction, Microfinance and Democratic Engagement
}

\author{
${ }^{1}$ George Mason University - Arlington Campus, 3434 N. Washington Blvd., Arlington, VA 22201-4411, USA, E-mail: \\ samwaijohnson@gmail.com
}

\begin{abstract}
:
This paper presents results from a study of the comparative effects of microfinance group lending, and individual lending technologies on measures of women's political capital in a fragile conflict-affected setting. Based on a quasi-experiment in Liberia, the two lending technologies were found to have significant effects on different measures of women's political capital, though the effects were greater for the group lending technology than those of the individual lending. The different effects are due to the program orientation of the two lending technologies which facilitate the development of more resources for communal activism and democratic values among group lending than individual lending borrowers. This impact of this effect will be minimal if factors that constrain the women's ability to invest their political capital are not addressed. Although more evidence would be required in order to generalize these results, they provide us insights about the political contribution of an economic intervention to post-conflict reconstruction.
\end{abstract}

Keywords: post-conflict reconstruction, democratic engagement, political capital, Liberia, microfinance DOI: $10.1515 /$ peps-2017-0048

\section{Introduction}

The provision of microfinance services has emerged as a complementary approach to the reconstruction of fragile and conflict-affected settings. Apart from providing financial resources that help conflict-shattered populations jump-start their post-conflict livelihoods, microfinance group lending also facilitates interactions among the populations including those made estranged by conflict (Doyle, 1998; Sile, 2013). While many post-conflict microfinance institutions award loans through group lending technology, there are others that use the individual lending technology. Group lending technology is used to provide credit services to borrowers who lack tangible collateral but have the guarantees of fellow borrowers about the ability to repay their loans. Under group lending technology, borrowers organize themselves into loan groups which bear the liability of a member's repayment default. By agreeing to bear the loan default liability for each other, group lending clients, in effect, function as co-insurers for the loan of each other (Ray, 1998). The rest of the group stands to lose its creditworthiness for future loan if it fails to fulfill the obligation of its defaulting member. Group lending microfinance provides its clients' training that enhances their ability to collectively address their financial issues, and exposure to external political resources that increases their political capabilities to democratically convey their preferences and demands to their political leaders and institutions (Hashemi, Schuler \& Riley, 1996; Kabeer, 2017; Sanyal, 2009). Individual lending technology, on the other hand, provides loans to individual borrowers who have the physical collateral to guarantee their loan repayment (Karlan \& Goldberg, 2011). The collateral is seized by the microfinance institution if the borrower defaults.

The lending technology used by a microfinance organization has both financial and nonfinancial effects on borrowers (Karlan \& Goldberg, 2011). One non-financial effect is the change clients' political capital (Kabeer, 2017). Birner and Wittmer (2000) describe political capital as the resource that endows citizens with the power to influence governance in the direction that protects their interests. Political capital provides the foundation for citizenship participation, providing citizens, especially the poor and marginalized with channels to democratically engage with the governance of their community or society (Birner \& Wittmer, 2000; Turner, 1999). Voting, contacting a public official, and participating in petitions, rallies or campaigns to influence a particular political or social outcome of governance in the interest of their constituencies are measures of political capital (Booth \& Richard, 1998). Elections, debates about community projects, political rallies, protests, and petitions provide avenues for political capital investment.

While post-conflict microfinance literature acknowledges microfinance's political contribution to postconflict reconstruction (Doyle, 1998), focus of this literature seems to be on the political effects of group lending 
microfinance; seemingly unexplored are the comparative political effects of these two lending technologies. This article is an attempt at probing these effects. By examining these effects, this paper extends the discussion about how group-targeted economic interventions such as microfinance can be used to stimulate the political inclusion and democratic engagement of marginalized and impoverished groups with post-conflict reconstruction.

This article is based on a carefully conducted quasi-experiment of women microentrepreneurs of the types of microfinance lending in Liberia, a fragile post-conflict country that used microfinance to increase women's political capital. The paper's hypothesis is that group lending microfinance has a greater effect on client's political capital than individual lending microfinance. The measures of political capital used in this study are limited to registering to vote, and contacting one's legislator to influence rules, laws or policies about problems facing your community. The choice of these variables is based on a review of the literature and interviews with key informants about female political capital in Liberia.

Liberia's reconstruction agenda calls for the inclusion of women at levels of the country's governance (Government of Liberia, 2008). Despite some efforts, this call has been challenged by several factors affect women's political capital in Liberia, which are political, economic, and cultural (Government of Liberia, 2008; Kellow, 2010; Principe, 2017). Politically, political parties privilege men over women for political decision-making at both the micro- and macro-levels. Culturally, women are believed to be more effective in the management of household chores than politics. Women also lack the economic resources to sustain political contests against traditionally established male candidates in both community and national elections. It is these factors that Liberia seeks to address at both the macro and the micro levels as it reconstructs through reserved legislative seats for women and the provision of microfinance services to build the political capabilities of grassroots women (Government of Liberia, 2008; Liberia Ministry of Commerce, 2011). The choice of microfinance is due primarily to its positive effect on women's economic and political agency.

More than 85 percent of women in Liberia are vulnerably unemployed, compared to nearly 70 percent of men (Liberia Institute for Statistics and Geo-Information Services (LISGIS), 2011). ${ }^{1}$ This limitation in women's economic status makes prohibitive the opportunity costs associated with their ability to influence political decisions or hold their political leaders accountable for their stewardship of the reconstruction process.

BRAC and Access Bank are the most prominent microfinance institutions in Liberia that have been engaged with Liberia's reconstruction endeavor. Both organizations provide financial services to low-income or impoverished individuals, mostly women, who are owners of microenterprises. ${ }^{2}$ While Access Bank provides individual loans, BRAC provides group loans to its clients. Prominent among the individual loan products of Access Bank are the micro and super micro loans aimed particularly at microenterpreneurs. A micro loan is in the amount of $\$ 50$, and a super microloan is $\$ 100$. In order to qualify for a loan, a prospective client must have an established business, a property equivalent in value to the size of the loan as collateral, and a guarantor from his/her community of residence.

The group lending of BRAC requires clients seeking loan services to organize themselves into village loan organizations of 25-40 members with no immediate family members in the same group (BRAC Microfinance Company Liberia, 2012). Membership to each group is determined through an assortative matching process, with each group member serving as a co-insurer for the loan of at least one fellow group member. Through this process, clients self-select themselves into loan groups based on their perceived risk of repayment default of each other (Armendariz \& Morduch, 2010). Each village loan group is then sub-divided into smaller groups of five. Each group elects its own leader, whose responsibility is to organize weekly meetings, collect the weekly repayments of the loan from each member, and submit the repayments to the credit officer assigned to the group. Loan sizes to each group range from $\$ 50$ to $\$ 500$, and the amount is awarded for up to 10 months with weekly repayments (BRAC Microfinance Company Liberia, 2012). New borrower groups meet about four times prior to loan disbursement and are given training about basic loan management, the program's objectives and modes of operation. After these initial meetings, they meet weekly to discuss credit decisions and make their loan repayments. BRAC has more than 10,000 clients in seven of Liberia's 15 counties (Central Bank of Liberia 2011).

Liberia's choice of microfinance to build the political capital of grassroots women is due to the positive effect of microfinance on clients' political capital in other settings (Hashemi, Schuler \& Riley, 1996; Mosley, Olejarova \& Alexeeva, 2004; Sanyal, 2009). However, the studies examining women's political capital in Liberia seems to be focused on women's legislative representation. For instance, Sims (2012) examined the effect of the existing political structures of the country on women's participation in the political decisions of the country. These structures include the Women Legislative Caucus of Liberia, political parties, and the electoral system of Liberia. Cole (2011) interrogates the effect of Liberian laws on women's ability to seek elective offices. Moran and Pitcher (2004), on the other hand, investigated the role of women in mediating an end to the conflict, and the reconstruction of the rural parts of the country. 
Birner and Wittmer (2000) point to the distinction between the political capital held by public officials such as the women legislators and that held by private citizens such as the grassroots women: the political capital held by the women legislators is "structural political capital" and that held by grassroots women is "instrumental political capital" (Birner \& Wittmer, 2000, pp. 4-6). Instrumental political capital does not only endow citizens with the power to engage their public officials, but creates an incentive for public officials to be accountable to their citizens through their responses to the voting choices and the concerns of citizens about the way of governance as expressed at public forums or campaigns and petitions (Cornwall, 2000; Verba, 2006). Thus, focusing on the macro political factors that affect women's legislative representations or the political capital of women legislators leaves unanswered questions about the effects of such micro-level interventions, as microfinance, on the ability of grassroots women to convey their political preferences or influence Liberia's reconstruction process in the political direction that protects their interests.

\section{Post-conflict reconstruction and political capital}

Post-conflict reconstruction is a process of (re)building institutions of participatory and inclusive governance in a conflict-affected society. This facilitates the society's transition from violent conflict to sustainable peace and economic development. At its core is the democratic engagement of citizens in political decision-making, wealth distribution, and questions of public accountability at both the community and the state levels. While the market is considered the central mechanism for wealth distribution, its ability to perform this function is determined by the nature of existing post-conflict political institutions (Acemoglu \& Robinson, 2012). Wealth distribution is therefore more a political than an economic question which is addressed through dialogue between the state and the society, and among groups estranged by conflict.

Political capital facilitates this type of dialogue. It empowers citizens with the ability to convey their preferences, and competing concerns for reconstruction and peace to political leaders or institutions of governance. This provides a non-violent pathway for the conflict-affected population to increase their voice and influence on the shape and direction of the reconstruction agenda. The existence of this pathway helps the population to hold their political leaders and governance institutions accountable at both the micro and the macro levels. This makes reconstruction more people-centered, and responsive to the competing aspirations of the conflictaffected populations, irrespective of their ideologies. By making the reconstruction process responsive to the competing aspirations of the population, political capital helps a post-conflict society to address not only the root cause but function as a catalyst for social transformation, reducing the incentives for a relapse to violence. This also contributes to inclusion, and the building of effective, legitimate and accountable state institutions (Jackson, 2005; UNSG, 2014).

\section{Post-conflict microfinance and political capital}

A wealth of literature about post-conflict microfinance explores the effect of microfinance on varying measures of clients' political capital (Bernal-Garcia, 2008; De Haan \& Lakwo, 2010; Doyle, 1998). However, the focus of this literature is on the political effect of group lending. A noted exception, however, is the work by Roxin et al. (2010). Roxin et al. (2010) conducted a quasi-experiment of 122 randomly selected clients of group lending and individual lending microfinance in Sierra Leone to evaluate the comparative social, political, and economic effects of the two microfinance lending technologies on women clients. The treatment group comprised both group lending and individual lending clients, and the control group comprised women who were not clients but were engaged in the same trade as the treatment group members. The following indicators were used to measure the effects of microfinance lending: (a) material empowerment, including changes in income, ownership of assets, fulfillment of basic needs and earning capacities; (b) cognitive empowerment, including changes at the level of knowledge, skills, and awareness of the wider environment; (c) perceptual self-esteem, self-confidence; and (d) relational empowerment, including changes relating to social interaction (e.g. decision-making, bargaining power, participation, self-reliance, organizational strength and mobility).

They found no effect of microfinance lending on the political empowerment of the women, especially the women's ability to organize collective actions to aid their political participation in decision-making. This was due to the limited experience and training among the women in organizing collective action and their primary focus, especially the women in the group lending microfinance program, on improving their credit-worthiness with the microfinance institutions rather than on increasing their political capital. Mayoux (2001) has noted that microfinance could negatively affect the political empowerment of clients if it focuses primarily on financial efficiency. These analyses present limited evidence about the effects of microfinance lending on clients' national 
level political engagement measured by their registration to vote in national elections, or contact their legislators privately or collectively to discuss problems facing their communities. The focus of this article is these national level political effects of microfinance based on the hypotheses below.

\section{Theoretical framework and hypotheses}

As stated earlier, the hypothesis of this article is that group lending microfinance has a greater effect on the political capital of clients than individual lending microfinance. The literature suggests intra-group interactions as a plausible channel through which microfinance affects the political capital of its clients (Hashemi, Schuler \& Riley, 1996; Kabeer, 2017; Mosley, Olejarova \& Alexeeva, 2004; Sanyal, 2009) - the ability for clients to contact their legislators to influence public policy or give their views about some matters affecting their communities, and to register to vote in an election. This effect is associated with the orientation of group lending microfinance which nudges clients towards social intermediation and communal activism through group formation and the holding of regular group meetings (Booth \& Richard, 1998; Nelson, 2013; Sanyal, 2009, pp. 542-546). The requirement for group formation and the holding of regular group meetings by group members provides an incentive for group members to cooperate, and develop the skills needed to collectively solve both financial and non-financial problems that may be affecting members' businesses, households, and communities (Kabeer, 2017; Mosley, Olejarova \& Alexeeva, 2004; Sanyal, 2009). These skills are developed through the exposure of the group to resources that are supplied through the private interactions of individual members with various strata of society (Hashemi, Schuler \& Riley, 1996), including the media, lawyers, and other civil society agents. These resources include knowledge about women's rights and their civic responsibilities, and the means of exercising these rights and responsibilities are supplied to group members. Individual members who accessed these resources through their personal interactions with civil society organizations share them with other group members during group meetings.

This knowledge-sharing increases the political awareness and capabilities of members to develop forms of activism and democratically engage with their political leaders around specific political issues that support the development of themselves, their communities, and protects their individual interests at the state and the community levels (Booth \& Richard, 1998; Hashemi, Schuler \& Riley, 1996; Mosley, Olejarova \& Alexeeva, 2004; Sanyal, 2009, pp. 542-546). The membership to these loan groups provide the group members a collective identity through which they define themselves in relations to others and the types of collective action in which to engage. Group members participating in the group's collective actions compare the cost associated with their engagement in the collective actions organized by their loan groups with the selective benefits to be gained from their groups after the collective actions (Chong, 1991; Sanyal, 2009, pp. 542-546; Tarrow, 1998). These benefits include maintaining group membership and social standing with fellow group members, and avoiding ridicule or ostracism from the loan groups when the collective action is done. The loan group's ability to deny members' access to future loans in addition to these benefits for their failure to honor the group's collective decisions (Armendariz \& Morduch, 2010) provides the mechanisms through which the loan group influences members' participation in collective actions defined by the group. These collective actions include contacting political leaders to give some views or to influence rules, laws or policies about some important problem facing their communities.

On the other hand, the individual lending microfinance program lacks the mechanism to influence members to organize communal loan groups or develop skills for cooperative entrepreneurship or collective action. The individual lending microfinance institution, which requires clients to gather at a central location to receive or repay their loans, provides little incentive for continuous interactions or collective problem-solving among its clients. While the women do engage each other during these meetings, the frequency of these interactions is limited compared to group lending clients. They have no incentive to meet before or during the life of their loans like their group lending counterparts, except maybe during the days of repayments. As a result, individual lending clients are less likely to generate structures for the supply of political resources that could empower them like group lending clients. Hence,

Hypothesis 1: Group lending clients are more likely to contact their legislators than individual lending clients to give some views or to influence rules, laws or policies about some important problem facing your community.

Turning to participation in elections, we focus on clients' registering to vote. The resources that group lending avails to its clients foster the respect for democratic values among members. These values enhance members' ability to take democratic actions that protect both their personal and the collective interests of their group or communities (Booth \& Richard, 1998; Chong, 1991; Sanyal, 2009). These actions include the exercise of their civic 
duty of voting or registering to vote in an election. By choosing to exercise their voting responsibilities, group members align with specific political preferences, and symbols that they consider relevant to addressing both their short-term private political interests, and the long term interest of their communities (Chong, 1993, p. 890; Schwartz, Caprara \& Vecchione, 2010). It is through this pursuit of essential short-term and long-term benefits that the associational activities of the loan groups mediate the development of political activism within group members. The development of political activism nurtures among members an increased desire to influence the performance of elected officials by taking actions to vote during elections (Booth \& Richard, 1998). The cost associated with losing the economic and non-economic benefits provided by membership in the loan group functions as an incentive that increases members' participation in the collective activism of the loan group by registering to vote during elections. On the other hand, the comparatively limited interactions among individual lending microfinance clients do not build or strengthen platforms that inculcate democratic values among its clients, such as the importance of registering to vote in an election. Hence,

Hypothesis 2: Group lending clients are more likely to register to vote than individual lending clients.

These hypotheses recognize that these political effects of microfinance may be limited by the prevailing political context. The political context shapes the behavior of communal activist groups, such as microfinance loan groups that nurture of citizens' political capital. For instance, a repressive political state impedes the development of citizens' political capital. The political context of Liberia is however assumed to be supportive of the development of political capital, given the focus of the country's reconstruction on participatory democracy and inclusive governance (Government of Liberia, 2008).

\section{Data and sampling methodology}

The data for this study were obtained from responses in a survey questionnaire that was administered to 127 participants in a carefully designed quasi-experiment conducted in Liberia's Greater Monrovia. The experiment comprised a treatment group of borrowers of the individual lending Access Bank, and the group lending BRAC Micofinance Company (BRAC), and a control (pipeline) group of microentrepreneurs who were qualified for loan membership in either microfinance program but had not been admitted. A random assignment of the research participants to the treatment and the control group would have been the ideal for this study. This was not possible because the sampling frame for the random sampling was not available. Participants were therefore admitted through a targeted sampling procedure.

Targeted sampling uses indicator-based qualitative and quantitative data to systematically estimate a sampling frame for populations for whom a formal sampling frame may not be available, and convenience sampling is not adequately rigorous to meet the objectives of the research design of random sampling (Semaan, Lauby \& Liebman, 2002; Watters \& Biernacki, 1989). The indicator-based sampling frame is generated through a multistage process that involves: developing a sampling frame of the locations of the target population based on interviews with individuals and organizations who were knowledgeable about the study population; identify and map the targeted sample from the non-targeted sample based on the variables of interest; randomly select locations for sampling from the developed sampling frame; and go to selected sites and identify and interview individuals eligible for participation in the research.

For this study, the sampling frame was estimated through the following procedure: a mapping exercise that identified the geographic locations of the borrowers of the two organizations and members of the control (pipeline) group across Monrovia; this was done based on a research of the Central Bank of Liberia's database, and conversations with officers of the two microfinance organizations, and micro-entrepreneur leaders in the market centers located across Monrovia. Drawing on, Hashemi, Schuler, and Riley (1996) and Maldonado and Gonzalez-Vega (2008), the following indicators guided these conversations and research: gender (respondents should females); occupation (respondents should be microentrepreneurs of at least a year); and microfinance membership (respondents should BRAC microfinance clients for at least a year). This was followed by the demarcation of the areas into clusters of microfinance activities of the individual lending microfinance organization, Access Bank, and the group lending organization, BRAC, based on borrowers densities, and the indicators mentioned earlier.

This procedure resulted in a sampling frame of an estimated 1200 borrowers of which more than 50 percent were group lending borrowers, and the remaining were individual borrowers. A sample size of 375 was estimated from the sampling frame, ${ }^{3}$ this size included 300 respondents from the treatment group, equally split between the individual and the group lending microfinance program; 25 percent of this sample size was included to account for the control (pipeline) group. The final stage of the sampling process was contacting and interviewing the respondents, using Biernacki and Waldorf (1981) "chain referral" technique. 
Using this technique, clients belonging to the treatment, and control groups in each of the selected research sites, who had been earlier identified during the cluster/community mapping exercise, provided the initial links in the chain of respondents; they were asked to identify their fellow borrowers during the survey. The initial targeted sample size of about 375 respondents had to be revised downward due to the ravaging spread of Ebola across Monrovia at the time. This revision was done through an iterative process that ensured that the final sample size reflected the particular qualities for each cluster and groups, enhancing the credibility of the study. This targeted sampling procedure resulted in a final sample size of 127 research participants included in the treatment and a control (pipeline) groups, spread across five loan groups, and two market centers in three business districts of the Greater Monrovia area. The distribution of the research participants by clusters is shown in Table 1 below.

Table 1: Distribution of research participants by treatment and control (pipeline) groups.

\begin{tabular}{lrr}
\hline Research classification & Membership size & Percent \\
\hline Individual lending microfinance & 35 & 27.55 \\
Group lending microfinance & 62 & 48.81 \\
Control (pipeline) group & 30 & 23.62 \\
Total & 127 & 100.00 \\
\hline
\end{tabular}

\subsection{Characteristics of respondents}

All of the respondents in this study were women aged 19-58 years. The average respondent had an elementary education; the highest educated respondent had a post-senior high school education, while the least educated had no formal education. In terms of the duration of their microenterprises (i.e. business duration), the women had been engaged in microentrepreneurship for an average of nearly 10 years, with the longest being 27 years, and the shortest duration of only 1 year. The average business duration of respondents in the individual lending, and the group lending microfinance institutions was about 12 and 11 years, respectively, and that of the control (pipeline) group was nearly 6 years. The membership duration of the group lending microfinance program ranged from 1 to 4 years, and that of the individual lending from 1 to 7 years.

\subsection{Operational definitions of survey variables}

The measures of political capital and the other variables used in this study were derived from several questions in the survey questionnaire. The series of questions related specifically to the different measures of political capital were developed through extensive observation, analysis, and discussion with key informants about women's political capital in Liberia. These measures are: registering to vote, and contacting one's legislator to give some views or to influence rules, laws or policies about some important problems facing your community. The question about the "registered to vote" referenced the Liberian legislative election which was scheduled for November 2014, the year of the survey. The operational measures of the political capital variables and other variables derived from the survey questionnaire for this study are described below.

\subsubsection{Registered to vote}

Specifically, the questionnaire asked: "With regard to the forthcoming Legislative elections, have you registered or updated your voter's registration in order to vote?" The responses ranged from "I have updated my voter's registration/registered to vote" to "I did not have time to register/update my voter's registration." Other responses included "Refused to answer" and "I was prevented from updating my registration/registering by a polling officer." Responses are coded 1 to indicate that the respondent had decided to vote, and 0 to indicate that respondent had decided not to vote. Thus, the response "I have updated my voter's registration/registered to vote" was coded 1, while responses ranging from "I have decided not to vote," "I did not have time to register/update my voter's registration" to I was prevented from updating my registration/registering by a polling officer" were coded 0 . The responses "Refused to answer" or "Neither agree nor disagree" were dropped along with Missing data. 


\subsubsection{Contacted one's legislator to give some views or to influence rules, laws or policies about some important problem facing your community?}

Respondents were asked: "How often have you contacted your legislative representative to give your views or to influence rules, laws or policies about some important problem facing your community?" The responses range from the respondent stating that she has contacted her legislator "Just once or twice a year," or "Everyday" to has "Never" contacted her legislator. Responses are coded 1 to indicate that the respondent had made contact with her legislator at least once a year, and 0 to indicate that respondent had never contacted her legislator. Thus, the response "I have contacted my legislator everyday" or "just once or twice a year" was coded 1, while the response "I have never contacted my legislator" was coded 0 . The responses "Refused to answer" or "Neither agree nor disagree" were dropped along with Missing data.

\subsubsection{Indicator of lending technology}

This variable was based on whether the respondent was registered with either a group lending microfinance, an individual lending microfinance institution or a part of the control (pipeline) group. Control (pipeline) group members were not members of the two microfinance institutions but were qualified for loans from either of them. A dummy variable was created in which a respondent who was receiving loan from either the individual or the group lending microfinance institution is coded 1. In the analysis the reference category is control (pipeline) group. A separate variable measures the length of time (recorded in years) that a respondent had been a member or loan recipient from a particular microfinance organization - membership duration.

\subsubsection{Control variables}

The analysis includes three control variables. These variables which indicate the socioeconomic status and the demographic characteristics of the respondents are: the respondent's age (coded in years), education level, (coded either as the respondent has some level of formal education or not), and overall living condition (based on respondent's rough assessment of her living condition compared to a year before this survey); the other control variable measures the duration (in years) of respondent's microenterprise business. The question about overall living condition specifically asked "In general, how would you describe your present living condition compared to a year ago?" The responses ranged from much worse to much better. Other responses were "Don't Know", and "Refused to talk." Responses were coded 1 for responses stating that respondent believes her overall living condition was improving compared to 1 year earlier, and 0 for responses stating that respondent does not believe that her overall living condition was improving compared to 1 year earlier. About education level, respondents were asked about the highest level of education they had completed at the time of the survey, with responses ranging from no formal school to post-graduate education. No formal education was coded 0 , while responses ranging from informal school only (including Koranic schooling) to post-graduate education were coded 1 . The response "Refused to answer" was dropped along with missing data.

\subsubsection{The issue of self-selection bias}

One challenge that this study faced is the issue of self-selection bias. This issue of self-selection bias occurs because of "systematic differences" in the background variables of the individuals who are enlist for participation in the program and those who choose not to participate (Maldonado \& Gonzalez-Vega, 2008; Hashemi, Schuler \& Riley, 1996). As a result of these differences in background variables, the individuals that are likely to participate in such programs as microfinance are usually relatively more empowered, or motivated about accomplishing the program's goals than those who do not participate. If not controlled for, the differences in these variables may affect the attribution of the program effects (Meyer, 2002). Hashemi, Schuler, and Riley (1996) suggest the use of longitudinal data as one remedy to adjust for this bias. In instances where longitudinal data are not available, it is important to identify the background variables of the participants that could influence the self-selection bias and use appropriate statistical techniques to adjust for this bias.

In addition to controlling for the respondents' background variables in the statistical models, the use of a control (pipeline) method in the sampling helps to minimize the self-selection bias. Maldonado \& GonzalezVega (2008, p. 2442) demonstrate that a control (pipeline) group makes a good comparison group if its members have been put through the same "systematic credit-worthiness criterion" screening as those in the treatment group. Since the two microfinance institutions in this study use similar credit-worthiness screening criteria, the 
control (pipeline) group members for either institution within the same location of the treatment group should be comparable to the treatment group members. ${ }^{4}$ Thus, the pipeline group of clients of the group lending group program who had been systematically screened and were awaiting their loans provided a better control (pipeline) group for the treatment group (Baker, 2000; Maldonado \& Gonzalez-Vega, 2008 (2008). The control (pipeline) group was therefore similar to the treatment group based on gender (all respondents were females), location, socioeconomic occupation (respondents were micro entrepreneurs of at least a year), and the loan requirement criterion.

Drawing on Maldonado and Gonzalez-Vega (2008) and Hashemi, Schuler, and Riley (1996), the following were identified as background variables that could lead to self-selection bias: age, business duration, education level, and overall living condition. A review of these background variables of the treatment group (the group lending clients, the individual lending clients), and the control (pipeline) group suggests some self-selection bias, but no statistically significant differences were found in most of these variables between the treatment group and the control (pipeline) group.

As shown in Table 2 below, although the control (pipeline) group respondents were more likely to rate their overall living condition as improving than the respondents in the treatment group, the living conditions of the respondents in the treatment group were less likely to be worse than the respondents in the control (pipeline) group as they all come from the same socioeconomic group. The statistical models for this study partially adjust for the self-selection bias by controlling for age, education, overall living condition, membership duration, and business duration. The membership duration variable was included in the statistical models to investigate the effects of the lending technologies on political capital over time. A significant effect of the membership duration variable on the political capital variables would suggest an effect of the lending technology even on members who were already more empowered before joining the program (Hashemi, Schuler \& Riley, 1996).

Table 2: Background variables and membership duration of study participants.

\begin{tabular}{|c|c|c|c|}
\hline Variable & $\begin{array}{r}\text { Individual } \\
\text { lending }\end{array}$ & $\begin{array}{l}\text { Group } \\
\text { lending }\end{array}$ & $\begin{array}{r}\text { Control (pipeline) } \\
\text { group }\end{array}$ \\
\hline Age (mean years) & $43(7.2)^{*}$ & $41(8.5)^{*}$ & $37(9.7)^{*}$ \\
\hline Business duration (mean years) & $12(6.9)^{*}$ & $10(7.3)^{*}$ & $6(4.5)^{*}$ \\
\hline $\begin{array}{l}\text { Education (\% of respondents who completed certain level of } \\
\text { school including Quranic reading) }\end{array}$ & 77 & 63 & 63 \\
\hline Overall living condition ( $\%$ of respondents saying it is better) & 33 & 56 & 64 \\
\hline Membership duration (mean years) & $4(1.7)^{*}$ & $3(1.2)^{*}$ & $\mathrm{n} / \mathrm{a}$ \\
\hline
\end{tabular}

*Means with standard deviations in parenthesis.

\section{Empirical analysis}

This paper estimates two logistic regression models with the following specification to determine the political effects of the lending technologies of microfinance:

Regression model :

$$
\operatorname{Logit}_{\mathrm{i}}=\alpha_{0}+\alpha_{1} \mathrm{X}_{\mathrm{i} 1}+\alpha_{2} \mathrm{X}_{\mathrm{i} 2}+\alpha_{3} \mathrm{X}_{\mathrm{i} 3}+\alpha_{4} \mathrm{X}_{\mathrm{i} 4}+\alpha_{5} \mathrm{X}_{\mathrm{i} 5}+\alpha_{6} \mathrm{X}_{\mathrm{i} 6}+\alpha_{7} \mathrm{X}_{\mathrm{i} 7}+\mu
$$

where $Y_{i}$ predicts: (i) the probability that a woman who is a member of a microfinance program registered to vote in the 2014 Liberian senatorial election versus a control (pipeline) group member ( $y=1$, if the woman registered to vote, and $0=$ if the woman did not register to vote); and (ii) the probability that a woman who is a member of a microfinance program contacted her legislator to give her views or to influence rules, laws or policies about some important problem facing her community versus a control (pipeline) group member $(\mathrm{y}=1$, if the woman contacted her legislator, and $0=$ if the woman did not contact her legislator); $X_{i 1}$ refers to borrowers in the group lending microfinance institution, coded as a dummy variable, with $1=$ group lending borrower, and $0=$ respondent in either the individual lending microfinance institution or control (pipeline) groups; $X_{\mathrm{i} 2}$ refers to borrower in the individual microfinance institution coded as a dummy variable, with $1=$ individual lending, and $0=$ respondent in either group lending or control (pipeline) group; $\mathrm{X}_{\mathrm{i} 3}$ refers to microfinance membership duration of the respondent; $X_{i 4}$ refers to the respondent's age; $X_{i 5}$ refers to the education level of the respondent ; $X_{i 6}$ refers to the duration of the microenterprise owned by the respondent; and $X_{i 7}$ refers to 
the overall living condition of the respondent compared to a year ago; $\alpha_{1}$, and $\alpha_{2}$ are the effects of the group lending, and the individual ending microfinance institutions, respectively. Based on the literature reviewed, the lending technologies are expected to have positive effects on the political capital variables - registered to vote, and contact legislator; the effect is however expected to be greater for group lending than individual lending.

The results summarized in the Table below show the effects of the lending technologies on the political capital variables of the women borrowers compared to their counterparts in the control (pipeline) group. The results are presented in odds ratios along with their $95 \%$ confidence intervals, and p-values for the membership duration, group lending technology, and individual lending technology. An independent variable has a statistically significant effect if its p-value $<0.05$. The models, as seen below, adjust for business duration, and the demographic variables discussed earlier. The effects of the business duration and demographic variables are not discussed in these results because the focus of this paper is not concerned about their effects. Each row in the Table shows a separate regression model; the dependent variables of registered to vote, and contacting legislators are shown in Column 1.

The effects of the two lending technologies are shown in Columns 2 and 3 in Table 3. Both the group lending, and the individual lending technologies have negative and significant effects on the dependent variable, registered to vote. Their effects on the other the dependent variable, contacted legislators, are negative but insignificant. The negative effects of the two lending technologies on registered to vote indicate that clients of both lending technologies have lesser odds of registering to vote. These negative effects of the lending technologies on the dependent variables are not consistent with the hypothesis. Instead of positive effects as hypothesized, these results suggest that the lending technologies have negative effects on clients' political capital.

Table 3: Effects of the individual lending and the group lending technologies on the measures of political capital: odd ratios $\mathrm{p}$-values and $95 \%$ confidence intervals from logistic regression models.

\begin{tabular}{|c|c|c|c|c|c|c|c|c|c|c|c|c|}
\hline \multirow{3}{*}{$\begin{array}{l}\text { Dependent } \\
\text { variable }\end{array}$} & \multirow{2}{*}{\multicolumn{4}{|c|}{$\frac{(1)}{\text { Membership duration }}$}} & \multirow{2}{*}{\multicolumn{4}{|c|}{$\frac{(2)}{\text { Individual lending technology }}$}} & \multirow{2}{*}{\multicolumn{4}{|c|}{$\frac{(3)}{\text { Group lending technology }}$}} \\
\hline & & & & & & & & & & & & \\
\hline & $\begin{array}{l}\text { Odds } \\
\text { ratio }\end{array}$ & p-Value & \multicolumn{2}{|c|}{$\begin{array}{r}95 \% \\
\text { confidence } \\
\text { interval }\end{array}$} & $\begin{array}{c}\text { Odds } \\
\text { ratio }\end{array}$ & p-Value & \multicolumn{2}{|c|}{$\begin{array}{r}95 \% \\
\text { confidence } \\
\text { interval }\end{array}$} & $\begin{array}{l}\text { Odds } \\
\text { ratio }\end{array}$ & p-Value & \multicolumn{2}{|c|}{$\begin{array}{r}95 \% \\
\text { confidence } \\
\text { interval }\end{array}$} \\
\hline \multicolumn{13}{|c|}{ Political measures } \\
\hline $\begin{array}{l}\text { Register } \\
\text { to vote }\end{array}$ & $1.865^{*}$ & 0.002 & 1.250 & 2.782 & $0.051^{*}$ & 0.001 & 0.008 & 0.314 & $0.217^{*}$ & 0.032 & 0.053 & 0.880 \\
\hline $\begin{array}{r}\text { Contact } \\
\text { legislators }\end{array}$ & $1.831^{*}$ & 0.013 & 1.138 & 2.944 & 0.232 & 0.215 & 0.023 & 2.331 & 0.2646 & 0.167 & 0.040 & 1.741 \\
\hline
\end{tabular}

*Statistically significant at the $5 \%$ level; **statistically significant at the $1 \%$ level.

Models adjust for age, education level, business duration, overall living condition, individual lending technology, and group lending technology.

These negative effects may be due to several factors which this paper cannot separate statistically with its cross-sectional data. One may be that clients were focused greatly on strengthening their businesses and credit ratings for future credits during the earliest period of their membership and deferring the development of their political capital to the latter period of their membership with the program. The statistical models used by this paper are unable account for the effects that may occur during the earlier period.

The estimated coefficients of the group lending are greater than those of the individual lending microfinance program; this difference could be due to the unequal sizes of the samples of respondents from the two microfinance programs in this study. The sample size for the group lending is about two times that for the individual lending microfinance program. This difference in the sample sizes could be responsible for the estimated difference in coefficients of the two lending technologies. Thus, the effects of the group lending microfinance could be smaller than estimated. More evidence will be therefore required in order for this result to be generalizable; hence, it should be reported with caution.

Membership duration has a positive and statistically significant effect on the measures of political capital: registered to vote, and contacting one's legislators. This suggests that clients have greater odds of registering to vote, and contacting their legislators with each additional year of microfinance membership. While this shows a true effect of microfinance lending (Hashemi, Schuler \& Riley, 1996), it doesn't show whether this effect is the same for both lending technologies. The models were therefore re-estimated with an interaction term of membership duration and the lending technologies variables in order to examine this relationship. The Appendix shows the effects of the interaction terms on the two measures of political capital.

The results of the effects of interaction term of membership duration and individual lending microfinance are positive but insignificant on all of the political capital variables. The interaction term of membership du- 
ration and group lending technology is positive and statistically significant on both registering to vote, and contacting one's legislator at the five percent level. These significantly positive effects indicate that each additional year of membership increases the odds of group lending clients registering to vote, and contacting their legislators than the members of the control (pipeline) group.

\section{Conclusion}

This paper presents an analysis of the comparative effects of the lending technologies of microfinance on women's political capital in a fragile post-conflict society. The analysis suggests that participation in microfinance lending programs empowers women to register to vote, and contact their legislators to discuss problems affecting their communities. The effect is greater for the group lending than the individual lending microfinance. While this difference in effects may be influenced by self-selection bias, it is also due to the program orientation of the group lending technology which facilitates the development of more resources for communal activism among group lending than individual lending borrowers.

The orientation of the group lending microfinance towards social intermediation facilitate the creation of a social platform that enables borrowers to interact and over time develop an increased awareness about the social and political problems facing their communities, while increasing their confidence and agency to seek political solutions to these problems. Group interactions over economic matters increase the women's political agency to participate, and negotiate the terms of governance of their communities and society, thus increasing their ability to register to vote, and contact their legislators about these issues. Increasing the women's political agency also creates a path for the women to communicate with state institutions about issues that they care about deeply. This enhances the political capability of the women to collectively get democratically engaged with the reconstruction process as a major non-state actor in Liberia's reconstruction process.

While this article is not intended to suggest that participating in microfinance lending programs is the ultimate means for increasing the political capital of women borrowers in fragile settings, it suggests however that microfinance lending catalyzes a cost-effective means of communal activism that increases the political capability of its clients to participate and negotiate the terms of governance by their elected officers, while aiding the financial inclusion and economic security of the population. The effectiveness of this political contribution of microfinance to the post-conflict reconstruction is dependent however upon the nature of state institutions. The nature of these institutions could either increase or decrease the cost associated with citizens' political engagement with post-conflict reconstruction. Although more evidence would be required in order to generalize these results they provide us insights about the political contribution of a non-political group-based intervention to post-conflict reconstruction.

\section{Appendix}

The interactive effects of membership duration and the two lending technologies.

\begin{tabular}{|c|c|c|c|c|c|c|c|c|}
\hline \multirow[t]{2}{*}{ Dependent variable } & \multicolumn{4}{|c|}{ Individual lending*membership duration } & \multicolumn{4}{|c|}{ Group lending*membership duration } \\
\hline & $\begin{array}{r}\text { Odds } \\
\text { ratio }\end{array}$ & p-Value & $95 \% \mathrm{c}$ & $\begin{array}{l}\text { fidence } \\
\text { nterval }\end{array}$ & $\begin{array}{r}\text { Odds } \\
\text { ratio }\end{array}$ & p-Value & $95 \%$ & $\begin{array}{l}\text { idence } \\
\text { terval }\end{array}$ \\
\hline \multicolumn{9}{|l|}{ Political capital measures } \\
\hline Registered to vote & 1.399 & 0.172 & 0.864 & 2.267 & $2.715^{*}$ & 0.001 & 1.48 & 4.979 \\
\hline Contacted legislators & 1.579 & 0.123 & 0.883 & 2.823 & $2.307^{*}$ & 0.031 & 1.077 & 4.941 \\
\hline
\end{tabular}

\section{Notes}

1 The Liberia Institute for Statistics and geo-Information Services (LISGIS) considers "vulnerable employment rate" a more useful indicator about employment. People who are in vulnerable employment work in "precarious circumstances" and are "unlikely to have the benefits of favorable conditions at work such as an assured salary, pension, sickness benefit or job security." See Liberia Institute for Statistics and Geo-Information Services, Report on the Liberia Labour Force Survey 2010 (Monrovia: Liberia Institute for Statistics and Geo-Information Services, 2011, p. xi). 
2 A microenterprise in Liberia is a "very small, usually family business with family labor or perhaps one or two full time employees." See Liberia Ministry of Commerce (2011), p. 10.

3 The sample size was estimated with this formula to calculate sample size: $n=N /[1+N(e) 2]$, where, $n=$ the sample size, $N=$ the population, and $\mathrm{e}=$ the level of precision, which for this study is 0.05 .

4 A major credit-worthiness criterion for both borrowers of the group lending and the individual lending microfinance programs in addition to being an owner of a microenterprise is the production of at least one co-insurer against loan default; the co-insurer under both lending technologies is liable for repayment default by clients (Ray, 1998; Women's World Banking, 2015; Background Interview with Access Bank Liberia Loan Officers).

Article note: This article derives from the author's doctoral dissertation, "The effects of the liability structure of microfinance on the political capital of post-conflict clients: Implications for peacebuilding and economic development."

\section{References}

Acemoglu, D., \& Robinson, J. (2012). Why nations fail: The origins of power, prosperity, and poverty. New York: Crown Publishers.

Armendariz, B., \& Morduch, J. (2010). The economics of microfinance (2nd ed.). Cambridge and London: MIT Press.

Baker, J. L. (2000). Evaluating the impact of development projects on poverty: A handbook for practitioners. Washington, D.C.: The World Bank.

Bernal-Garcia, J. (2008). Post-conflict microfinance and social reconciliation: Overcoming barriers through process mitigation. Stanford Journal of Microfinance, 1,9 .

Biernacki, R., \& Waldorf, D. (1981). Snowball sampling: Problems and techniques of chain referral sampling. Sociological Methods \& Research, 10(2), 141-163.

Birner, R., \& Wittmer, H. (2000). Converting social capital into political capital: How do local communities gain political influence? A theoretical approach and empirical evidence from Thailand and Colombia. A Paper Delivered at the Eighth Biennial Conference of the International Association for the Study of Common Property at Indiana University, Bloomington, Indiana.

Booth, J., \& Richard, P. (1998). Society, political capital, and democratization in Central America. The Journal of Politics, 60(3), 780-800.

BRAC Microfinance Company Liberia. (2012). Liberia annual report. Monrovia, Liberia: BRAC Microfinance Liberia. Accessed January $12,2017$. http://www.brac.net/sites/default/files/ar2012/BRAC\%2oLiberia.pdf.

Central Bank of Liberia. (2011). Microfinance: Contributing to employment and poverty reduction. Central Bank of Liberia Newsletter, 3 (2), 6.

Chong, D. (1991). Collective action and the civil rights movement. Chicago, IL: The University of Chicago Press.

Chong, D. (1993). How people think, reason, and feel about rights and liberties. American Journal of Political Science, 37(3), 867-899.

Cole, S. (2011). Increasing women's political participation in Liberia: Challenges and potential lessons from India, Rwanda and South Africa. Washington, DC: IFES Fellowships in Democracy Studies.

Cornwall, A. (2000). Beneficiary, consumer, citizen: Perspectives on participation for poverty reduction, Sida studies (Vol. 2). Stockholm: Swedish International Development Cooperation Agency.

De Haan, L., \& Lakwo, A. (2010). Rethinking the impact of microfinance in Africa: 'Business change' or social emancipation. The European Journal of Development Research, 22(4), 529-545.

Doyle, K. (1998). Microfinance in the wake of conflict: Challenges and opportunities, development alternatives. Bethesda, Maryland, USA: Microenterprise Best Practices (MBP) Project.

Government of Liberia. (2008). Lift Liberia poverty reduction strategy. Monrovia, Liberia: Covernment of Liberia.

Hashemi, S., Schuler, R., \& Riley, A. (1996). Rural credit programs and women's empowerment in Bangladesh. World Development, 24(4), 635653.

Jackson, J. (2005). Protecting livelihoods in violent economies. In K. Ballentine \& H. Nitzschke (Eds.), Profiting from Peace: Managing the resource dimensions of civil war (pp. 153-182). Colorado: Lynne Rienner.

Kabeer, N. (2017). Economic pathways to women's empowerment and active citizenship: What does the evidence from Bangladesh tell us? Journal of Development Studies, 53(5), 649-663.

Karlan, D., \& Goldberg, N. (2011). Microfinance evaluation strategies: Notes on methodology and findings. In M. Labie \& B. Armendariz (Eds.), The Handbook of Microfinance (pp. 17-58). London: World Scientific Publishing Company.

Kellow, T. (2010). Women, elections and violence in West Africa: Assessing women's political participation in Liberia and Sierra Leone. London: International Alert.

Liberia Institute for Statistics and Geo-Information Services (LISGIS). (2011). Report on the Liberia Labour Force Survey 2010. Liberia: LISCIS Monrovia.

Liberia Ministry of Commerce. (2011). Poverty alleviation and wealth creation through small enterprise development: Rationale, policy and implementation framework for MSME development in Liberia 2011-2016. Monrovia, Liberia: Ministry of Commerce.

Maldonado, J., \& Conzalez-Vega, C. (2008). Impact of microfinance on schooling: Evidence from poor rural households in Bolivia. World Development, 36(11), 2440-2455.

Mayoux, L. (2001). Tackling the down side: Social capital, women's empowerment and micro-finance in Cameroon. Development and Change, 32(3), 435-464.

Meyer, R. (2002). Track Record of Financial Institutions in Assisting the Poor in Asia. Paper for the Capacity Building Seminar on the Role of Financial Intermediaries for Poverty Reduction. Asian Development Bank Institute, Singapore.

Moran, M. H., \& Pitcher, A. (2004). The "basket case" and the "poster child": Explaining the end of civil conflicts in Liberia and Mozambique. Third World Quarterly, 25(3), 514. 
Mosley, P., Olejarova, D., \& Alexeeva, E. (2004). Microfinance, social capital formation and political development in Russia and Eastern Europe: A pilot study of programmes in Russia, Slovakia and Romania. Journal of International Development, 16(3), 407-427.

Nelson, C. (2013). Community-based providers. In J. Ledgerwood, J. Earne \& C. Nelson (Eds.), The new microfinance Handbook: A financial market system perspective (pp. 162-163). Washington, DC: The World Bank.

Principe, M. (2017). Women in nonviolent movements, United States Institute of Peace (USIP) Special Report 399. Washington, DC.

Ray, D. (1998). Development economics. India: Oxford University Press.

Roxin, H., Berkmüller, H., Koller, P. J., Lawonn, J., Pooya, N., \& Schappert, J. (2010). Economic empowerment of women through microcredit: The case of microfinance investment and technical assistance facility (MITAF). SLE Publication Series 240. Retrieved from http://edoc.huberlin.de/series/sle/240/PDF/240.pdf.

Sanyal, P. (2009). From credit to collective action: The role of microfinance in promoting women's social capital and normative influence. American Sociological Review, 74(4), 529-550.

Schwartz, S. H., Caprara, G. V., \& Vecchione, M. (2010). Basic personal values, core political values, and voting: A longitudinal analysis. Political Psychology, 31(3), 421-452.

Semaan, S., Lauby, J., \& Liebman, J. (2002). Street and network sampling in evaluation studies of HIV risk-reduction interventions. AIDS Reviews, 4(4), 213-223.

Sile, E. (2013). Financial inclusion in fragile states. In T. Triki \& I. Faye (Eds.), Financial inclusion in Africa (pp. 94-104). Accra, Chana: African Development Bank.

Sims, B. M. (2012). Women in transition: A critical analysis of women's civic and political participation in Liberia. Pretoria, South Africa: Idasa.

Tarrow, S. (1998). Power in Movement: Social Movements and Contentious Politics. Cambridge, UK: Cambridge University Press.

Turner, R. (1999). Entrepreneurial neighborhood initiatives: Political capital in community development. Economic Development Quarterly, 13(1), 15-22.

UNDP. (2006). The first state of the environment report for Liberia. Monrovia, Liberia: UNDP-Liberia.

UNSC (UN Secretary Ceneral). (2014). Peacebuilding in the aftermath of conflict. Report of the Secretary-Ceneral. Document A/69/399S/2014/694. Retrieved from https://reliefweb.int/sites/reliefweb.int/files/resources/N1454555.pdf.

Verba, S. (2006). Fairness, equality, and democracy: Three big words. Social Research: An International Quarterly of Social Sciences, 73(2), 499-540.

Watters, J., \& Biernacki, P. (1989). Targeted sampling: Options for the study of hidden populations. Social Problems, 36(4), 416-430.

Women's World Banking. (2015). Individual lending for low-income women entrepreneurs: An inclusive approach. New York: Women's World Banking. 